\title{
Rozwijanie kompetencji kulturalnych dorosłych osób z niepełnosprawnością intelektualną - projekt naukowy „Kulturalni w Toruniu"
}

\begin{abstract}
Abstrakt
Kompetencje kulturalne są składową kompetencji społecznych, których rozwijanie jest istotnym zadaniem w życiu człowieka. Celem badania było ukazanie rozwoju kompetencji kulturalnych dorosłych osób z umiarkowaną oraz znaczną niepełnosprawnością intelektualną dzięki ich uczestnictwu w wydarzeniach kulturalnych. Badanie zostało przeprowadzone w ramach naukowego projektu grantowego „Kulturalni w Toruniu". Celem praktycznym projektu było zdobycie nowych kompetencji społecznych, w tym kulturalnych, przez dorosłe osoby z umiarkowaną oraz znaczną niepełnosprawnością intelektualną poprzez ich czynny udział w wydarzeniach kulturalnych. Podczas trwania projektu zrealizowano badania wstępne oraz badania końcowe dotyczące kompetencji kulturalnych uczestników projektu z wykorzystaniem wywiadu częściowo ustrukturyzowanego, obserwacji uczestniczącej oraz Kwestionariusza Kompetencji Społeczno-Zawodowych (KKSZ) dla ONU i ich opiekunów. W projekcie uczestniczyło pięć dorosłych osób z niepełnosprawnością intelektualną, którzy wzięli udział w - samodzielnie wybranych - jedenastu wydarzeniach kulturalnych. Wyniki badań wykazały zmiany w definiowaniu pojęcia kultura przez uczestników badań, poszerzenie ich wiedzy dotyczącej miejsc związanych z kulturą, zdobycie nowych umiejętności praktycznych podczas uczestnictwa w wydarzeniach kulturalnych, a także rozwój umiejętności decyzyjnych. Rezultaty potwierdzają, iż uczestnictwo w kulturze oddziałuje na kompetencje społeczne.
\end{abstract}

Słowa kluczowe: niepełnosprawność intelektualna, kompetencje kulturalne, kompetencje społeczne, wydarzenia kulturalne, dorosłość.

\footnotetext{
* Interdyscyplinarna Szkoła Doktorska Nauk Społecznych Academia Rerum Socialium na Uniwersytecie Mikołaja Kopernika w Toruniu.
} 


\title{
Developing the Cultural Competences of Adults with Intellectual Disability - The "Cultured in Toruń" Research Project
}

\begin{abstract}
Cultural competences are components of social competences, the development of which is an important task in human life. The aim of the study was to show the development of cultural competences of adults with severe intellectual disability through their participation in cultural events. The study was conducted as part of the "Cultured in Toruń" scientific grant project. The practical aim of the project was for participants to acquire new social competences, including cultural ones, through their active participation in cultural events. The research on the cultural competences of the participants was conducted through a semi-structured interview and the SocioProfessional Competency Questionnaire for people with mental disabilities and their carers, and also a participant observation. Five adults with intellectual disability took part in eleven events selected by themselves. The results of the study showed changes in the definition of "culture" by the participants, their knowledge of places related to culture, development of new practical skills during participation in cultural events, and development of decision-making skills. The results confirm that participation in culture has an impact on social competences.
\end{abstract}

Keywords: intellectual disability, cultural competences, social competences, cultural events, adulthood.

\section{Wprowadzenie}

Zagadnienie obecności osób z niepełnosprawnością intelektualną w życiu społecznym, a w szczególności w życiu kulturalnym stosunkowo niedawno stało się szerzej dyskutowane w literaturze. $\mathrm{W}$ badaniach dominują rozważania skoncentrowane na aspektach partycypacji osób z niepełnosprawnościami w sporcie (Blinde, Taub 1999; Brittain 2004; Baranowski 2006; Thomas, Smith 2008; Molik i in. 2010; Michaluk 2011; Pieszak 2012) czy turystyce (Kaganek, Stanuch 2005; Chojnacki 2007; Preisler 2011; Furmanek 2011; Zajadacz 2012; Furmanek 2014; Vila, Darcy, González 2015). Znikoma liczba opracowań poświęcona jest natomiast partycypacji w kulturze (Żuraw 1996; Candlin 2003; Poria, Reichel, Brandt 2009; Rhoads 2009; Lister, Tanguay, Snow, D’Amico 2009; Nowak 2015). Prezentowane rozważania dotyczą przede wszystkim osób z niepełnosprawnością fizyczną czy sensoryczną. Osoby z niepełnosprawnością intelektualną bardzo często zostają pomijane $\mathrm{w}$ badaniach w tym zakresie (Pawlik 2015). Według najnowszej klasyfikacji DSM-51 niepełnosprawność intelektualna jest „zaburzeniem rozpoczynającym się w okresie

\footnotetext{
1 Diagnostyczny i Statystyczny Podręcznik Zaburzeń Psychicznych Amerykańskiego Towarzystwa Psychiatrycznego (Diagnostic and Statistical Manual of Mental Disorders - DSM-5, 2013).
} 
rozwoju i obejmuje deficyty zarówno w zakresie funkcjonowania intelektualnego, jak i adaptacyjnego w obszarach dotyczących rozumienia pojęć, funkcjonowania społecznego oraz w dziedzinach praktycznych" (Gałecki, Święcicki 2015: 35). W procesie diagnozowania zwraca się uwagę na następujące sfery: pojęciową, społeczną oraz praktyczną, które warunkują to, w jaki sposób osoba radzi sobie w codziennych sytuacjach (Żyta 2014).

Celem przeprowadzonych badań było poznanie uwarunkowań kształtowania się kompetencji kulturalnych dorosłych osób z niepełnosprawnością intelektualną w stopniu umiarkowanym i znacznym poprzez uczestnictwo badanych w wydarzeniach kulturalnych. Badania zostały zrealizowane podczas projektu naukowego „Kulturalni w Toruniu”, w którym uczestniczyło pięć dorosłych osób z niepełnosprawnością intelektualną. Wzięli oni udział w samodzielnie wybranych jedenastu wydarzeniach kulturalnych na terenie Torunia. Realizacja projektu zakładała przeprowadzenie badań początkowych i końcowych, które oddzielone były trzema miesiącami spotkań, rozmów na temat kultury i uczestnictwem w wielu różnorodnych wydarzeniach kulturalnych ${ }^{2}$.

Dokonując ujednolicenia terminologicznego, należy wskazać na wielość pojęć określających uczestnictwo człowieka w kulturze. Oprócz wykorzystywanego wcześniej określenia uczestnictwo w kulturze wyróżnić można jeszcze m.in. aktywność kulturalną, konsumpcję kulturalną bądź życie kulturalne (Żuraw 1996: 15). W niniejszym opracowaniu będę stosować te pojęcia zamiennie. Samo pojęcie uczestnictwa w kulturze zostało opisane przez Agnieszkę Kłosowską jako „swoista sfera ludzkiej aktywności, polegająca na udziale w symbolizacji, czyli na wytwarzaniu symbolicznych przekazów oraz na odbieraniu i interpretowaniu przekazów wytworzonych przez innych ludzi" (Kłosowska 1972: 22).

Pojęcie kompetencji można rozumieć wielorako. Według słownika języka polskiego opisywane jest jako „zakres czyjejś wiedzy, umiejętności i doświadczenia” (Dubisz 2006: 186). Natomiast w szerszej definicji pojęcie kompetencji obejmuje „zbiór różnych predyspozycji człowieka, od których zależy sprawne wykonywanie działań, automatyczne kierowanie samorozwojem, pełnienie ról społecznych oraz organizacyjnych. Kompetencja jest pewną ukrytą cechą (metawłaściwością), która przejawia się w określonych zachowaniach" (Konarski 2006: 8-9).

Pojęciem obejmującym szereg umiejętności istotnych dla funkcjonowania w społeczeństwie, w skład których wchodzą również kompetencje związane z uczestnictwem w kulturze, są kompetencje społeczne (Baczała 2012). Beata Gumienny zwraca uwagę na fakt, iż posiadane przez osobę kompetencje społeczne determinują jej funkcjonowanie i podejmowanie codziennych zadań życiowych (Gumienny 2010). Sam proces kształtowania kompetencji społecznych „przebiega $\mathrm{w}$ toku treningu społecznego i jest wynikiem interakcji między wewnętrznymi

\footnotetext{
2 Artykuł stanowi część pracy magisterskiej pt. Kompetencje kulturalne dorosłych osób z niepełnosprawnościq intelektualnq pisanej pod kierunkiem dr hab. Ditty Baczały prof. UMK na Wydziale Nauk Pedagogicznych UMK w Toruniu.
} 
determinantami osobistymi a czynnikami społecznymi, podlegającymi zmianom, wpływom i transformacjom" (Gumienny 2010: 25). 0 kompetencjach kulturalnych jako składowej kompetencji społecznych pisze m.in. Ryszard Urbański-Korż. W ramach zaproponowanego przez autora podziału kompetencji społecznych (w aspekcie dotyczącym dziedzin życia społecznego i mechanizmów reglamentacji społecznej) wymienia on m.in. kompetencje dotyczące uczestnictwa w kulturze i realizacji czasu wolnego (Urbański-Korż 2000: 10-13).

Kompetencje społeczne osób z niepełnosprawnością intelektualną podlegają procesowi treningu społecznego zarówno w sposób naturalny (w środowisku rodzinnym), jak i instytucjonalny (w placówkach). Nie są zatem właściwością stałą. W przypadku osób z niepełnosprawnością intelektualną bardzo ważne jest odpowiednio organizowane wsparcie. Ditta Baczała oraz Katarzyna Dąbrowska podkreślają, iż „osoby z niepełnosprawnością intelektualną mają prawo do realizacji siebie we wszystkich sferach życia i do pełnego uczestnictwa w życiu społecznym" (Baczała, Dąbrowska 2013: 29). Należy zatem stwierdzić, iż tworzenie możliwości rozwoju kompetencji społecznych, w tym kompetencji kulturalnych, osobom $\mathrm{z}$ niepełnosprawnością intelektualną jest jednym $\mathrm{z}$ podstawowych elementów wsparcia.

Samo pojęcie kompetencji kulturalnych nie zostało jednoznacznie zdefiniowane. Katarzyna Olbrycht wskazuje, że określenie „kulturalny oznacza odznaczający się kulturą, przeniknięty kulturą, kulturowy natomiast to związany z kulturą" (Olbrycht 2014: 1). W stosunku do podejmowanych badań własnych zastosowano pojęcie kompetencji kulturalnych definiowane jako zakres umiejętności dotyczących uczestnictwa w kulturze obejmującej wszelkie formy aktywności kulturalnej (m.in. kino, teatr, restauracje, kawiarnie, koncerty muzyczne). Katarzyna Olbrycht, odwołując się do pojęcia kompetencji kulturalnej, wymienia następujące elementy:

- wiedza o kulturowych uwarunkowaniach, również historycznych,

- umiejętność intepretowania kontekstu przekazów kulturowych, umiejętność poszukiwania źródeł informacji dotyczących wydarzeń kulturalnych oraz możliwości uczestniczenia w kulturze (Olbrycht 2014: 14).

Natomiast w zakresie kształcenia postaw wobec kultury autorka wymienia:

- kształtowanie samodzielnych wyborów w kulturze,

- rozwijanie rozumienia roli kultury w życiu,

- rozwijanie umiejętności krytycznej oceny kultury i działań kulturalnych,

- motywowanie do samodzielnego uczestnictwa (bezpośredniego oraz pośredniego) w kulturze, a także wypowiadania własnych opinii oraz wymiany poglądów,

- kształtowanie refleksji nad kulturowymi wartościami, jej celami oraz realizacją tychże zamierzeń (tamże). 
Wartość rozwoju kompetencji kulturalnych podkreśla również nowe rozporządzenie Ministra Edukacji Narodowej z dnia 14 lutego 2017 r. w sprawie podstaw programowych dla uczniów z niepełnosprawnością intelektualną w stopniu umiarkowanym lub znacznym dla szkoły podstawowej i szkoły przysposabiającej do pracy (zwanej dalej Rozporządzeniem). W nowym akcie normatywnym zwrócono uwagę na potrzebę rozwijania kompetencji kulturalnych, nakładając również na szkołę obowiązek realizacji tego zagadnienia. Na podstawie punktu 13. Rozporządzenia wskazuje się na następujące treści:

- wdrażanie do korzystania z ośrodków i instytucji kultury,

- uczenie się właściwego zachowania w różnych miejscach i sytuacjach (teatr, kino, muzeum, wystawy, koncerty itp.),

- wdrażanie do udziału w różnych formach twórczości (formy parateatralne, muzykowanie, zajęcia plastyczne, imprezy itp.),

- uczenie się tworzenia własnych prac artystycznych (obrazy, kompozycje, projekty fotograficzne i filmowe, odgrywanie ról itp.) (Dz.U. z 2017 r., poz. 356: 233).

Zapis ten zawarty $\mathrm{w}$ polskim akcie prawnym jest potwierdzeniem tego, iż kompetencje kulturalne osób z niepełnosprawnością intelektualną powinny być kształtowane oraz rozwijane.

Samodzielne uczestnictwo w kulturze dorosłych osób z niepełnosprawnością intelektualną nie jest tematem często poruszanym $\mathrm{w}$ badaniach naukowych czy artykułach popularnonaukowych. Kontakt z kulturą wymienionej grupy ogranicza się jedynie do bardzo nielicznych grupowych wyjść organizowanych przez szkołę bądź inną placówkę, której są podopiecznymi, z pominięciem możliwości samodecydowania o wyborze aktywności. Badania potwierdzają wykluczenie z życia społecznego osób z niepełnosprawnością intelektualną. Grażyna Magnuszewska-Otulak (2009) wskazuje m.in. na utrudniony dostęp do służby zdrowia, dóbr kultury czy silne poczucie zagrożenia biedą. Zastanawiając się nad przyczynami tego stanu, można wskazać za autorką takie bariery aktywności społecznej osób z niepełnosprawnością intelektualną, jak: panujące stereotypy, trudniejszy dostęp do zatrudnienia, niższe dochody czy postawy społeczne (tamże). Ważnym zadaniem dla praktyki edukacyjnej jest poszukiwanie rozwiązań prowadzących do minimalizowania tego zjawiska.

Należy wskazać, że aktywne uczestnictwo w kulturze może pełnić różnorodne funkcje, wśród których wskazać można na funkcję rozrywkową, kompensacyjną, relaksacyjną, poznawczą, integracyjną oraz kreacyjną (Żuraw 1996). Aktywizacja społeczno-kulturalna osób z niepełnosprawnościami może stanowić zatem metodę wszechstronnego stymulowania rozwoju, która pozwala na ujawnienie się oraz doskonalenie różnorodnych zdolności, które sprzyjają efektywnej realizacji zadań życiowych (Dykcik 2003). Wiąże się to również z realizowaniem zadań związanych z dorosłością. Można jednoznacznie wskazać, że uczestnictwo w kulturze pełni 
ważną rolę w procesie społecznego usamodzielniania się osób z niepełnosprawnością (Jutrzyna 2005; Nowak 2015). Władysław Dykcik (2003) zauważa, że możliwości rozwoju osób z niepełnosprawnością intelektualną kształtowane poprzez aktywność kulturalną stanowią jeszcze tajemnicę, są niezbadane i niedoceniane. Niemniej jednak badacz ten spostrzega coraz więcej podejmowanych oddziaływań w zakresie rozwijania aktywności kulturalnej osób z niepełnosprawnością intelektualną, zwłaszcza w kontekście kształtowania ich postaw życiowych oraz zachowań adaptacyjnych, które stanowią mechanizm aktywujący społeczną autonomię tych osób (Dykcik 2003).

\section{Założenia badań własnych}

Podjęte badania nad rozwojem kompetencji kulturalnych mają typ praktyczny o charakterze diagnostycznym. Zastosowanie tego typu badań pozwala na rozpoznanie i opisanie określonego stanu rzeczy (Rubacha 2008). Dodatkowo badania te mogą być wskazówką dotyczącą praktycznych zmian w edukacji oraz ukazać kierunek rozwoju badanej problematyki. Jako strategię badawczą zastosowano badania jakościowe, postępując według schematu studium przypadku. Zastosowany schemat pozwala na badanie przypadków, które dotyczyć mogą zarówno pojedynczych osób (bądź grupy osób w podobnej sytuacji), instytucji, organizacji, jak również doświadczanych przez osoby zdarzeń (Flick 2010). Studium przypadku pozwala na opis oraz wyjaśnienie przebiegu i znaczenia zjawiska ogólnego, w którym uczestniczy jednostka lub grupa (Juszczyk 2013). W ramach prowadzonych badań dokonano opisu zjawiska, jakim jest uczestnictwo w wydarzeniach kulturalnych przez osoby z niepełnosprawnością intelektualną.

Do gromadzenia danych zastosowano technikę wywiadu częściowo ustrukturyzowanego, a także obserwację bezpośrednią uczestniczącą. Jako technikę uzupełniającą służącą do dokładnego opisu uczestników badań zastosowano Kwestionariusz Kompetencji Społeczno-Zawodowych dla osób z niepełnosprawnością intelektualną i ich opiekunów (KKSZ) autorstwa Marty Brodowskiej, Marty Kosteckiej-Rogowskiej oraz Beaty Kozak (2013). Zastosowane techniki pozwoliły na szerokie rozpoznanie badanego zagadnienia, wykorzystując do tego celu badania wstępne (przed rozpoczęciem właściwych działań projektowych) oraz badania końcowe (po zakończeniu udziału we wszystkich wydarzeniach). Jako technikę analizy danych zastosowano kodowanie i kategoryzację.

Celem prezentowanych badań było poznanie uwarunkowań kształtowania się kompetencji kulturalnych dorosłych osób z niepełnosprawnością intelektualną w stopniu umiarkowanym i znacznym przez uczestnictwo badanych w wydarzeniach kulturalnych. Precyzując zakres wydarzeń kulturalnych, w których brali udział uczestnicy badań, należy wymienić spektakle teatralne, pokazy filmowe w kinie, koncerty muzyczne w salach koncertowych, wyjścia do restauracji oraz wyjścia do kawiarni. Problematyka badawcza obejmuje kształtowanie się kompe- 
tencji kulturalnych osób z niepełnosprawnością intelektualną (m.in. rozumienie pojęcia kultury, wiedzy o miejscach związanych z kulturą, umiejętnościach wymaganych do uczestniczenia w niej) poprzez partycypację w wydarzeniach kulturalnych. Dodatkowo podjęto kwestię znaczenia, jakie uczestnictwu w kulturze nadają osoby z niepełnosprawnością intelektualną oraz możliwości rozwoju kompetencji społecznych właśnie poprzez aktywność kulturalną. Podczas realizacji badań postawiono następujące pytania badawcze:

Pytanie badawcze główne:

1. W jaki sposób partycypacja w wydarzeniach kulturalnych dorosłych osób z niepełnosprawnością intelektualną w stopniu umiarkowanym i znacznym przyczynia się do kształtowania ich kompetencji kulturalnych?

Pytania badawcze szczegółowe:

1.1. Jak zmienia się konceptualizacja kultury przez dorosłe osoby z niepełnosprawnością intelektualną (w stopniu umiarkowanym i znacznym) oraz ich wiedza na temat miejsc związanych z kulturą dzięki ich uczestnictwu w toruńskich wydarzeniach kulturalnych?

1.2. Jaką aktywność kulturalną przejawiają osoby z niepełnosprawnością intelektualną w stopniu umiarkowanym i znacznym?

1.3. Jakie umiejętności związane z uczestnictwem w kulturze posiadają w subiektywnej opinii dorosłe osoby z niepełnosprawnością intelektualną $\mathrm{w}$ stopniu umiarkowanym i znacznym?

1.4. Jakie znaczenie dorosłe osoby $\mathrm{z}$ niepełnosprawnością intelektualną w stopniu umiarkowanym i znacznym przypisują uczestnictwu w wydarzeniach kulturalnych?

1.5. Jak kształtują się wybrane kompetencje społeczne dorosłych osób z niepełnosprawnością intelektualną (w stopniu umiarkowanym i znacznym) dzięki ich uczestnictwu w toruńskich wydarzeniach kulturalnych?

\section{Opis uczestników badań}

Wyboru uczestników badań dokonano poprzez zastosowanie próby celowej, która składała się z pięciu dorosłych osób z umiarkowaną bądź znaczną niepełnosprawnością intelektualną - uczniów Szkoły Przysposabiającej do Pracy (SPdP). Uczestnicy badania wyrazili świadomą zgodę na udział w projekcie, co zostało dodatkowo potwierdzone podpisanym przez każdego z uczestników formularzem zgody. Imiona uczestników zostały zakodowane. W celu dokładnego przedstawienia uczestników badań stworzono tabelę (tabela 1), w której zaprezentowano respondentów oraz opracowane wyniki badań na podstawie Kwestionariusza Kompetencji Społeczno-Zawodowych. Wyniki wykazują małe zróżnicowanie między uczestnikami badań, co powoduje, że grupę badaną można uznać za homogeniczną w znaczeniu badań kwestionariuszem. 
Tabela 1. Opis uczestników badań na podstawie wyników Kwestionariusza Kompetencji Społeczno-Zawodowych (KKSZ) dla osób z niepełnosprawnością intelektualną i ich opiekunów

\begin{tabular}{|c|c|c|c|c|c|}
\hline Imię & Wiek & $\begin{array}{c}\text { Stopień } \\
\text { NI }\end{array}$ & Edukacja & $\begin{array}{c}\text { Ocena własnych } \\
\text { cech } \\
\text { i umiejętności }\end{array}$ & $\begin{array}{c}\text { Ocena cech } \\
\text { i umiejętności doko- } \\
\text { nana przez opiekunów }\end{array}$ \\
\hline Agnieszka & 23 & znaczny & $\begin{array}{l}\text { SPdP, } \\
3 \mathrm{kl} .\end{array}$ & $\begin{array}{l}\text { Aktywne rozwiązy- } \\
\text { wanie problemu, } \\
\text { gotowość do zmiany, } \\
\text { wewnętrzne poczu- } \\
\text { cie kontroli }\end{array}$ & $\begin{array}{l}\text { Średni poziom samo- } \\
\text { oceny, gotowość do } \\
\text { zmiany, zewnętrzne } \\
\text { poczucie kontroli, } \\
\text { w sytuacji stresowej } \\
\text { strategia ukierunkowa- } \\
\text { na na rozwiązanie } \\
\text { problemu }\end{array}$ \\
\hline Agata & 21 & $\begin{array}{l}\text { umiarko- } \\
\text { wany }\end{array}$ & $\begin{array}{l}\text { SPdP, } \\
3 \mathrm{kl} .\end{array}$ & $\begin{array}{l}\text { Aktywne rozwiązy- } \\
\text { wanie problemu, } \\
\text { gotowość do zmiany, } \\
\text { wewnętrzne poczu- } \\
\text { cie kontroli }\end{array}$ & $\begin{array}{l}\text { Średni poziom samoo- } \\
\text { ceny, gotowość do } \\
\text { zmiany, zewnętrzne } \\
\text { poczucie kontroli, } \\
\text { w sytuacji stresowej } \\
\text { strategia ukierunkowa- } \\
\text { na na unikanie }\end{array}$ \\
\hline Ada & 19 & $\begin{array}{l}\text { umiarko- } \\
\text { wany }\end{array}$ & $\begin{array}{l}\text { SPdP, } \\
3 \mathrm{kl} .\end{array}$ & $\begin{array}{l}\text { Aktywne rozwiązy- } \\
\text { wanie problemu, } \\
\text { gotowość do zmiany, } \\
\text { wewnętrzne poczu- } \\
\text { cie kontroli }\end{array}$ & $\begin{array}{l}\text { Średni poziom samoo- } \\
\text { ceny, gotowość do } \\
\text { zmiany, wewnętrzne } \\
\text { poczucie kontroli, } \\
\text { w sytuacji stresowej } \\
\text { strategia ukierunkowa- } \\
\text { na na rozwiązanie } \\
\text { problemu/unikanie }\end{array}$ \\
\hline Adam & 23 & znaczny & $\begin{array}{l}\text { SPdP, } \\
3 \mathrm{kl} .\end{array}$ & $\begin{array}{l}\text { Aktywne rozwiązy- } \\
\text { wanie problemu, } \\
\text { gotowość do zmiany, } \\
\text { wewnętrzne poczu- } \\
\text { cie kontroli }\end{array}$ & $\begin{array}{l}\text { Niski poziom samooce- } \\
\text { ny, gotowość do zmiany, } \\
\text { zewnętrzne poczucie } \\
\text { kontroli, w sytuacji } \\
\text { stresowej strategia } \\
\text { ukierunkowana na } \\
\text { rozwiązanie problemu }\end{array}$ \\
\hline Aleksander & 23 & $\begin{array}{l}\text { umiarko- } \\
\text { wany }\end{array}$ & $\begin{array}{l}\text { SPdP, } \\
3 \mathrm{kl} .\end{array}$ & $\begin{array}{l}\text { Aktywne rozwiązy- } \\
\text { wanie problemu, } \\
\text { gotowość do zmiany, } \\
\text { wewnętrzne poczu- } \\
\text { cie kontroli }\end{array}$ & $\begin{array}{l}\text { Średni poziom samoo- } \\
\text { ceny, gotowość do } \\
\text { zmiany, zewnętrzne } \\
\text { poczucie kontroli, } \\
\text { w sytuacji stresowej } \\
\text { strategia ukierunkowa- } \\
\text { na na rozwiązanie } \\
\text { problemu }\end{array}$ \\
\hline
\end{tabular}

Źródło: opracowanie własne na podstawie analizy wyników KKSZ. 
Różnicę zauważyć można między określeniem wewnętrznego bądź zewnętrznego poczucia kontroli, gdzie ocena własna badanych (wewnętrzne poczucie kontroli) nie zawsze pokrywa się z oceną opiekunów (w większości przypadków wskazują na zewnętrzne poczucie kontroli). Wyniki kwestionariusza są bazą wyjściową dla opisu grupy badanej według zmiennych zaproponowanych przez KKSZ. Zarówno uczestnicy badań, jak i opiekun wskazują na gotowość do zmiany. Wszyscy badani wykazują również umiejętność aktywnego rozwiązywania problemów (natomiast w opinii opiekunów w sytuacji stresowej stosują strategie ukierunkowane na rozwiązanie problemu bądź unikanie). Dokładna analiza wyników KKSZ wykracza poza zakres tego opracowania, natomiast pozwalają one na stworzenie opisu grupy badanej w kontekście ich kompetencji społeczno-zawodowych, które są pozycją wyjściową dla kompetencji kulturalnych.

\section{Rezultaty}

Rezultaty badań zostały zogniskowane wokół pięciu głównych zagadnień: konceptualizacji kultury, aktywności kulturalnej dorosłych osób z niepełnosprawnością intelektualną oraz jej znaczenia w ich subiektywnej opinii, umiejętności związane z uczestnictwem w kulturze dorosłych osób z niepełnosprawnością intelektualną oraz kształtowanie się wybranych kompetencji społecznych poprzez uczestnictwo w kulturze badanych.

W zakresie pierwszego aspektu, jakim jest konceptualizowanie kultury, między badaniem wstępnym oraz końcowym zauważono pewne zmiany. Samo pojęcie kultury nie jest jednoznacznie zdefiniowane w literaturze. Wincenty Okoń w ramach tego pojęcia wyróżnia: efekt i proces wytwarzania dóbr kultury, normy, wzory zachowań i wartości ludzkie oraz wszelkie dzieła wytworzone przez ludzi (Okoń 2001). W początkowej fazie projektu (przed uczestnictwem w wydarzeniach kulturalnych) badani traktowali kulturę jako synonim odpowiedniego zachowania się. To, w jaki sposób zachowuje się osoba kulturalna, jest dokładnie opisane przez uczestników poprzez wymienienie rzeczy, które składają się na odpowiednie zachowanie: „nie krzyczeć”, „nie śmiecić”, „zachowywać się w miejscu publicznym”, „znać zasady”, „nie bić”, „proszę, dziękuję, przepraszam, do widzenia”. Odpowiedzi te według definicji przedstawionej przez W. Okonia mieszczą się w kategorii „normy, wzory zachowań i wartości ludzkie”. Podczas drugiego wywiadu uczestnicy projektu zaczęli łączyć słowo kultura również z szeroko pojętym uczestnictwem w kulturze. Działania podjęte w ramach projektu zaliczali jako definicję kultury, np. „kultura to też to co robiliśmy, jak chodziliśmy do różnych miejsc, zwiedzaliśmy”. Pozwoliło to na wskazanie drugiej kategorii w zakresie konceptualizacji kultury, jaką jest kultura jako forma spędzania czasu wolnego (aktywne spędzanie czasu poza domem w określonych miejscach). Dla uczestników badań kultura zyskała również wymiar aktywny, oparty na doświadczaniu i przeżywaniu. 
Następnym elementem bezpośrednio związanym z konceptualizacją tego pojęcia była wiedza uczestników projektu na temat miejsc związanych z kulturą. Już podczas pierwszego wywiadu badani wskazali na dziesięć różnorodnych miejsc, które uznają jako miejsca związane z kulturą. Najczęściej wskazywane z nich to kino oraz restauracja. Można domniemywać, że część ze wskazanych miejsc, jak np. przychodnia zdrowia, miejsce pracy, kościół czy szkoła związane są z poprzednią kategorią, wskazaną podczas definiowania kultury, jaką było odpowiednie zachowanie się. Badani mogli zatem wskazać miejsca, w których należy zachowywać się odpowiednio, a więc „kulturalnie”. Podczas drugiego wywiadu, oprócz wskazywanych wcześniej miejsc, wyróżnione zostały trzy kolejne nowe miejsca: teatr, hotel oraz koncert (jako wydarzenie). Teatr był wymieniany bardzo często, co zapewne miało związek z wizytami w teatrze podczas trwania projektu. Można wskazać na zależność między uczestnictwem w wydarzeniach kulturalnych przez badanych $\mathrm{w}$ ramach projektu a zmianami w ich konceptualizacji kultury oraz wiedzy. Badane aspekty wchodzą również w zakres kompetencji kulturalnych. Jednym z elementów tych kompetencji jest bowiem „znajomość źródeł informacji o wydarzeniach kulturalnych, możliwościach i miejscach kontaktów z kulturą" (Olbrycht 2014: 14). Można zatem powiedzieć, że nastąpił rozwój kompetencji kulturalnych uczestników projektu w tym zakresie.

W aspekcie związanym z aktywnością kulturalną uczestników badań jednoznacznie można wskazać, iż w minimalnym stopniu uczestniczą oni w życiu kulturalnym. Incydentalne aktywności dotyczą wizyt w kinie oraz $\mathrm{w}$ restauracji, gdzie pierwsza z nich podejmowana jest jako obowiązkowa aktywność szkolna, natomiast druga jako wyjścia rodzinne. Żaden z dorosłych uczestników projektu nigdy wcześniej nie podejmował żadnej aktywności związanej z kulturą całkowicie samodzielnie, z własnego wyboru. Pomimo tego, że deklarują oni chęć uczestnictwa $\mathrm{w}$ kulturze oraz zauważają szereg zalet z tym związanych (co potwierdza kolejne pytanie badawcze), barierę stanowią m.in. kwestie finansowe oraz strach przed opuszczeniem domu.

Kolejnym poruszanym w badaniach zagadnieniem był zakres umiejętności związanych z uczestnictwem w kulturze, które posiadają uczestnicy projektu. Uczestnicy badań zwracają uwagę na to, iż zarówno w kinie, jak i w teatrze: „należy zachowywać się spokojnie”, „nie hałasować”, „być grzecznym”, „zachować ciszę”, „nie śmiać się z byle czego”. Wskazanie prawidłowych zasad zachowania w restauracji również nie sprawiło uczestnikom badania trudności. Wskazują oni na zachowanie spokoju, spożywanie posiłku zgodnie z normami społecznymi czy też dbanie o własny wygląd podczas jedzenia, co potwierdzają odpowiedzi: „Kulturalnie, grzecznie, nie bawić się jedzeniem, nie krzyczeć, noża i widelca używać. Nie ubrudzić się”, „Noo... trzeba, jeść normalnie żeby się na przykład, żeby nie nabrudzić, żeby nie krzyczeć, żeby nie przeszkadzać innym". Zatem można stwierdzić, że pomimo tego, iż w ograniczonym stopniu uczestniczą w życiu kulturalnym, posiadają oni dużą wiedzę teoretyczną. Podobna sytuacja pojawia się w przypadku odpowiedzi dotyczących umiejętności zakupu biletu oraz wyboru filmu w kinie. 
Uczestnicy badań wiedzą, w jaki sposób można kupić bilet w kinie oraz znają sposoby zapoznania się z repertuarem kinowym, gdzie wymieniają takie formy, jak: strona internetowa kina, „przejście się do kina”, plakaty z filmami w kinie bądź na słupach informacyjnych. Natomiast żaden z uczestników badań nie wykorzystywał nigdy posiadanej wiedzy teoretycznej w praktyce, ponieważ zgodnie odpowiadają, iż nigdy nie kupowali biletów w kinie ani nie mieli możliwości samodzielnego wyboru filmu.

Istotnym zagadnieniem były również powody uczestniczenia w kulturze w opinii dorosłych osób z niepełnosprawnością intelektualną. Zarówno w początkowej fazie badań, jak i końcowej uczestnicy badań uważali, iż uczestnictwo w kulturze ma szereg pozytywnych aspektów. Argumentowali swoje wypowiedzi następująco: „można fajnie spędzić czas z drugą osobą”, „poprawić nastrój”, „dowiedzieć się czegoś”, „obejrzeć ciekawy film”, „zobaczyć coś nowego”, „zobaczyć coś innego niż w telewizji”, „posłuchać innej muzyki”, spędzić czas w „innym klimacie”, „nie siedzieć w domu”. Według H. Żuraw uczestnictwo w kulturze spełnia następujące funkcje: rozrywkową, kompensacyjną, relaksacyjną, poznawczą, integracyjną oraz kreacyjną (Żuraw 1996). Wskazywane przez badanych skategoryzowane odpowiedzi można przyporządkować do wymienionych przez autorkę funkcji (tabela 2).

Tabela 2. Funkcje uczestnictwa w kulturze wg H. Żuraw (1996) a skategoryzowane odpowiedzi respondentów

\begin{tabular}{|c|c|c|c|c|c|}
\hline $\begin{array}{c}\text { Funkcja } \\
\text { rozrywkowa }\end{array}$ & $\begin{array}{c}\text { Funkcja } \\
\text { kompensa- } \\
\text { cyjna }\end{array}$ & $\begin{array}{c}\text { Funkcja } \\
\text { relaksa- } \\
\text { cyjna }\end{array}$ & $\begin{array}{c}\text { Funkcja } \\
\text { poznawcza }\end{array}$ & $\begin{array}{c}\text { Funkcja } \\
\text { integra- } \\
\text { cyjna }\end{array}$ & $\begin{array}{c}\text { Funkcja } \\
\text { krea- } \\
\text { cyjna } \\
\end{array}$ \\
\hline $\begin{array}{l}\text { - przyjemne } \\
\text { doświadczenie } \\
\text { („coś fajnego”), } \\
\text { - doświadczenie } \\
\text { czegoś wyjątkowe- } \\
\text { go, niecodzienne- } \\
\text { go, („zacząłem } \\
\text { lubić ten klimat, } \\
\text { jest inaczej niż } \\
\text { w domu, lepiej”), } \\
\text { - forma spędzania } \\
\text { czasu wolnego, } \\
\text { („nie będzie się } \\
\text { człowiek nudził, } \\
\text { nie będzie siedział } \\
\text { w domu”). }\end{array}$ & $\begin{array}{l}\text { - możliwość } \\
\text { odreagowania } \\
\text { negatywnych } \\
\text { emocji („,bo się } \\
\text { wtedy relaksu- } \\
\text { jemy, zapomi- } \\
\text { namy o na- } \\
\text { szych proble- } \\
\text { mach”) } \\
\text { - zachowanie } \\
\text { wynikające } \\
\text { z wewnętrznej } \\
\text { potrzeby } \\
\text { („no jak ktoś } \\
\text { potrzebuje, ma } \\
\text { taką potrzebę } \\
\text { to idzie”). }\end{array}$ & $\begin{array}{l}\text { - sposób na } \\
\text { odpoczynek } \\
\text { („żeby } \\
\text { człowiek się } \\
\text { odprężył, } \\
\text { zapomniał } \\
\text { o proble- } \\
\text { mach, żeby } \\
\text { się trochę } \\
\text { rozerwał”). }\end{array}$ & $\begin{array}{l}\text { - możliwość } \\
\text { poszerzania } \\
\text { własnej } \\
\text { wiedzy („no } \\
\text { można się } \\
\text { dowiedzieć } \\
\text { czegoś, jak jest } \\
\text { jakiś ciekawy } \\
\text { film”), } \\
\text { - możliwość } \\
\text { odkrywania } \\
\text { nowych rzeczy } \\
\text { („,no żeby tak } \\
\text { zobaczyć no, } \\
\text { coś innego niż } \\
\text { zawsze”). }\end{array}$ & $\begin{array}{l}\text { - możliwość } \\
\text { bezpośred- } \\
\text { niego } \\
\text { spotkania } \\
\text { z drugą } \\
\text { osobą („,żeby } \\
\text { można było } \\
\text { iść z kimś } \\
\text { a nie ciągle } \\
\text { przez telefon } \\
\text { z kimś, czy } \\
\text { tam przez } \\
\text { Facebooka”). }\end{array}$ & - \\
\hline
\end{tabular}

Źródło: opracowanie własne (kategorie zostały wyróżnione na podstawie wszystkich wypowiedzi respondentów, każda z nich opatrzona jest przykładowym fragmentem wywiadu). 
Jedyna funkcja, która została pominięta w wypowiedziach badanych, to funkcja kreacyjna. Według Hanny Żuraw dotyczy ona samego procesu tworzenia i pobudzenia twórczych zdolności jednostki (Żuraw 1996). Uczestnicy projektu nie stawiają siebie zatem w roli aktywnego twórcy kultury, a jedynie jej biernego odbiorcy.

Zmiany zauważono również w zakresie wybranych kompetencji społecznych. Obserwacji podlegały następujące obszary:

- podjęcie udziału w dyskusji grupowej nad wyborem wydarzenia kulturalnego (umiejętność dyskutowania w grupie, umiejętność prezentowania własnej opinii);

- wykazanie inicjatywy w procesie poszukiwania wydarzeń kulturalnych, np. wskazanie grupie, gdzie mogą poszukiwać źródeł, przygotowanie źródeł na spotkanie, własne poszukiwanie informacji i dzielenie się nimi na kolejnym spotkaniu (umiejętność poszukiwania źródeł informacji na wybrany temat, umiejętność przekazywania informacji innym osobom);

- wejście w interakcję z nieznaną osobą w celu rezerwacji stolika w kawiarni bądź restauracji, zakupu biletu na wydarzenie, zdobycie informacji o wydarzeniu;

- umiejętność dostosowania odpowiedniego stroju do okazji;

- punktualne przybycie do miejsca docelowego (umiejętność zaplanowania oraz organizacji dojazdu).

Analiza danych z obserwacji jednoznacznie wskazuje na rozwój wskazanych kompetencji społecznych $\mathrm{w}$ toku trwania projektu. Większość uczestników początkowo niechętnie brała udział w dyskusji grupowej, widoczne były trudności związane $\mathrm{z}$ wyrażaniem własnej opinii lub problemy $\mathrm{z}$ wchodzeniem $\mathrm{w}$ interakcję. Przyjmowana była postawa bierna - „niech Pani wybierze”. Zmiany w tym obszarze były widoczne po kilku spotkaniach. Uczestnicy projektu chętniej wyrażali własne zdanie bądź inicjowali rozmowę. Podobna sytuacja dotyczy kontaktu z osobą obcą (umiejętności wejścia w interakcję, osiągniecia zamierzonego celu, np. zakupu biletu). Początkowo uczestnicy projektu reagowali strachem bądź niechęcią w momencie, w którym samodzielnie musieli dokonać pewnej czynności, np. rozpocząć rozmowę z kelnerem. W związku z tym często wybierali między sobą osobę, która najchętniej się tego podejmowała. Niemniej jednak, po kolejnych spotkaniach uczestnicy projektu sami zaczęli chętnie „zgłaszać się” do tego, aby zarezerwować stolik w restauracji lub zakupić bilet w kasie. Według teorii Anny Matczak podejmowane w toku spotkań czynności można nazwać treningiem umiejętności społecznych, w ramach których uczestnicy projektu nabywali kompetencje społeczne, w skład których wchodzą konkretne schematy operacyjne (np. proces zakupu biletu) oraz wiedza - znajomość reguł społecznych (np. wiedza dotycząca tego, które ubrania można założyć do konkretnego miejsca) (Matczak 2007). Ze względu na dużą liczbę spotkań obserwacja została ograniczona do wybranych wątków. Prawdopodobnie rozwojowi uległy również inne kompetencje społeczne, które stanowiły pokłosie podejmowanych czynności. 


\section{Wnioski}

Korzystanie z dóbr kultury jest jednym z praw obywatelskich i niezbywalnym elementem życia osoby dorosłej. Odnosząc się do celu badań, należy wskazać, iż aktywne uczestnictwo w wydarzeniach kulturalnych dorosłych osób z niepełnosprawnością intelektualną w stopniu umiarkowanym i znacznym przyczynia się do rozwoju ich kompetencji kulturalnych oraz kompetencji społecznych. Wyniki wskazują dużą różnicę między faktycznym poziomem aktywności kulturalnej (mała aktywność) a potrzebami, które wykazują dorosłe osoby z niepełnosprawnością intelektualną (chęć uczestniczenia w wielu formach aktywności kulturalnej). Wydaje się, iż istotne znaczenie dla kształtowania się kompetencji kulturalnych miała możliwość samodecydowania badanych. Na przykładzie realizowanego projektu można zauważyć, iż stworzenie możliwości partycypacji w kulturze pozwoliło na bezpośredni rozwój wielu umiejętności poprzez aktywne i samodzielne uczestnictwo osób z niepełnosprawnością intelektualną w wydarzeniach kulturalnych. Rozwój kompetencji kulturalnych dotyczył dwóch poziomów - wiedzy oraz umiejętności praktycznych. W zakresie wiedzy na temat kultury zauważono zmianę w definiowaniu pojęcia kultura oraz poszerzenie wiedzy dotyczącej miejsc bezpośrednio związanych z kulturą. Natomiast w sferze rozwoju umiejętności praktycznych można wyróżnić zarówno umiejętności miękkie (decyzyjność, punktualność, umiejętność prezentowania własnego zdania, umiejętność pracy w grupie), a także umiejętności twarde (zakup biletu w kasie biletowej, rezerwacja stolika w restauracji, umiejętność poszukiwania źródeł wiedzy na temat wydarzeń kulturalnych, dobór odpowiedniego stroju, umiejętność korzystania z komunikacji miejskiej i poruszania się po mieście).

Wymienione umiejętności są jedynie częścią wszystkich pozytywnych skutków, które niesie uczestnictwo w kulturze. Badania wykazały, iż badane osoby z niepełnosprawnością intelektualną posiadają wiedzę na temat zasad uczestnictwa $\mathrm{w}$ kulturze, natomiast wiedza ta nie jest wykorzystywana w praktyce, w związku $\mathrm{z}$ tym nie przekształca się ona w konkretne umiejętności. Uczestnictwo w wydarzeniach kulturalnych wydaje się być ciekawą alternatywą do pracy nad rozwijaniem kompetencji społecznych ze względu na funkcję rozrywkową, którą pełni. Uczestnicy projektu jednoznacznie wskazywali, że udział w wybranych przez nich wydarzeniach był przyjemnym doświadczeniem, możliwością relaksu czy też niecodziennym, wyjątkowym przeżyciem. Jest to zatem forma przyjazna dla uczestników, która pozwala im się rozwijać w sposób nieświadomy, niezauważalny dla nich.

Bezpośrednie uczestnictwo osób z niepełnosprawnością intelektualną w życiu kulturalnym jest najlepszym sposobem na rozwój kompetencji kulturalnych, a także może stanowić możliwość rozwoju szeregu kompetencji społecznych. Warto natomiast podkreślić, iż badania te nie wyczerpują złożoności tego zagadnienia. Realizacja dalszych badań wykazujących powody niskiego poziomu uczestnictwa w wydarzeniach kulturalnych przez dorosłe osoby z niepełnosprawnością 
intelektualną pozwoli na szersze ujęcie tej problematyki w przyszłości, co może mieć bezpośrednie przełożenie na proces edukacji i rehabilitacji osób z niepełnosprawnością intelektualną. Wyniki badań nie są reprezentatywne dla całej populacji dorosłych osób z niepełnosprawnością intelektualną w stopniu umiarkowanym i znacznym. Wnioski z badań dotyczą wyłącznie badanej grupy osób. Eksploracja jest początkiem, preludium do dalszych, pogłębionych badań naukowych, dotyczących nierozpoznanej jeszcze problematyki kompetencji kulturalnych osób z niepełnosprawnością intelektualną.

\section{Bibliografia}

Baczała D. (2012) Niepełnosprawność intelektualna a kompetencje społeczne, Toruń, Wydawnictwo Uniwersytetu Mikołaja Kopernika w Toruniu.

Baczała D., Dąbrowska K. (2013) Kompetencje społeczne osób dorosłych z niepełnosprawnościq̨ intelektualnq̨ w: Rozwój społeczny osób z niepełnosprawnościq intelektualnq. Ograniczenia i możliwości w zakresie kompetencji społecznych, D. Baczała, J. Błeszyński (red.), Toruń, Wydawnictwo Adam Marszałek, s. 15-61.

Baranowski J. (2006) Aktywność fizyczna niepełnosprawnych intelektualnie stopnia lekkiego, „Zeszyty Metodyczno-Naukowe”, nr 21, s. 7-16.

Blinde E. M., Taub D. E. (1999) Personal empowerment through sport and physical fitness activity: Perspectives from male college students with physical and sensory disabilities, ,Journal of Sport Behavior”, 22 (2), s. 181-202.

Brittain I. (2004) Perceptions of disability and their impact upon involvement in sport for people with disabilities at all levels, „Journal of Sport and Social Issues”, 28 (4), s. 429-452.

Brodowska M., Kostecka-Rogowska M., Kozak B. (2013) Kwestionariusz Kompetencji Społeczno-Zawodowych KKSZ dla ONU i ich opiekunów, Poznań, Kapitał Ludzki.

Candlin F. (2003) Blindness, art and exclusion in museums and galleries, „International Journal of Art \& Design Education", 22 (1), s. 100-110.

Chojnacki K. (2007) Turystyka osób niepetnosprawnych intelektualnie jako forma rehabilitacji fizycznej, psychicznej i społecznej, Kraków, Akademia Wychowania Fizycznego im. Bronisława Czecha.

Dubisz S. (2006) Uniwersalny słownik języka polskiego, Warszawa, Wydawnictwo Naukowe PWN. 
Dykcik W. (2003) Aktywność w kulturze i sztuce podstawq edukacji i twórczego życia osób niepełnosprawnych w: Sztuka w życiu i edukacji niepełnosprawnych, E. Jutrzyna (red.), Warszawa, Wydawnictwo Akademii Pedagogiki Specjalnej, s. 9-18.

Flick U. (2010) Projektowanie badania jakościowego, tłum. P. Tomanek, Warszawa, Wydawnictwo Naukowe PWN.

Furmanek M. (2011) Czy człowiek niepełnosprawny ma szansę być pełnosprawnym turystą?, „Państwo i Społeczeństwo”, nr 1, s. 93-102.

Furmanek M. (2014) Turystyka wyjazdowa niepełnosprawnych ruchowo mieszkańców Krakowa - stan i potrzeby, „Turyzm”, nr 24 (2), s. 7-15.

Gałecki P., Święcicki Ł. (2015) Kryteria diagnostyczne z DSM-5, Wrocław, Desk reference, Edra Urban \& Partner.

Gumienny B. (2010) Kompetencje społeczne niepełnosprawnych intelektualnie wychowanków domów dziecka, Rzeszów, Wydawnictwo Uniwersytetu Rzeszowskiego.

Juszczyk S. (2013) Badania jakościowe w naukach społecznych. Szkice metodologiczne, Katowice, Wydawnictwo Uniwersytetu Śląskiego.

Kaganek K., Stanuch H. (2005) Modele regresyjne uprawiania turystyki aktywnej przez osoby niepetnosprawne wzrokowo i ruchowo, "Bio-algorithms and Med-systems”, nr $1(1 / 2)$, s. 221-226.

Kłoskowska A. (1972) Społeczne ramy kultury. Monografia socjologiczna, Warszawa, Państwowe Wydawnictwo Naukowe.

Konarski S. (2006) Kluczowe znaczenie kompetencji społeczno-psychologicznych we współczesnych koncepcjach i praktyce systemów edukacji ekonomistów i menedżerów w: Kompetencje społeczno-psychologiczne ekonomistów i menedżerów. Teoria. Badania. Edukacja, S. Konarski (red.), Warszawa, Szkoła Główna Handlowa w Warszawie, s. 7-21.

Lister S., Tanguay D., Snow S., D'Amico M. (2009) Development of a creative arts therapies center for people with developmental disabilities, „Art Therapy”, 26 (1), s. 34-37.

Magnuszewska-Otulak G. (2009) Uczestnictwo osób niepełnosprawnych w życiu społecznym, Warszawa, Oficyna Wydawnicza ASPRA-JR.

Matczak A. (2007) Kwestionariusz Kompetencji Społecznych KKS: podręcznik, wyd. II poprawione, Warszawa, Pracownia Testów Psychologicznych.

Michaluk T. (2011) Sport osób niepełnosprawnych w semiotyczno-filozoficznej perspektywie badawczej, „Fizjoterapia”, nr 19 (1), s. 41-48. 
Molik B., Zubala T., Słyk K., Kucharczyk B., Gryglewicz A. (2010) Motywacja osób niepełnosprawnych do uprawiania koszykówki na wózkach, „Postępy Rehabilitacji”, nr 2, s. 53-61.

Nowak A. (2015) Uczestnictwo osób niepełnosprawnych w kulturze, „Chowanna”, nr 1, s. $91-102$.

Okoń W. (2001) Nowy słownik pedagogiczny, Warszawa, Wydawnictwo Akademickie „Żak”.

Olbrycht K. (2014) Edukacja kulturalna wobec różnych obliczy współczesnego wykluczenia w: Edukacja kulturalna przeciw wykluczeniom, K. Augustyniak, M. Strońska-Zaremba (red.), Wrocław, Wrocławskie Centrum Twórczości Dziecka, s. 9-19.

Pawlik S. (2015) Sztuka jako sposób włączania osób z niepełnosprawnościq intelektualnq do społeczeństwa, „Interdyscyplinarne Konteksty Pedagogiki Specjalnej”, nr 5, s. 59-74.

Pieszak E. (2012) Aktywność fizyczna a jakość życia osób z ograniczonq sprawnościq, „Ecologia Humana”, nr 2 (10), s. 135-147.

Poria Y., Reichel A., Brandt Y. (2009) People with disabilities visit art museums: an exploratory study of obstacles and difficulties, "Journal of Heritage Tourism", 4 (2), s. 117-129.

Preisler M. (2011) Turystyka osób niepełnosprawnych, „Studia Periegetica”, nr 6, s. 27-36.

Rhoads L. (2009) Museums, meaning making, and memories: The need for museum programs for people with dementia and their caregivers, "Curator: The Museum Journal", 52 (3), s. 229-240.

Rubacha K. (2008) Metodologia badań nad edukacja, Warszawa, Wydawnictwo Akademickie i Profesjonalne.

Thomas N., Smith A. (2008) Disability, sport and society: An introduction, London, Routledge.

Urbański-Korż R. (2000) Kompetencje społeczne dorosłych. Język - dobro - piękno - śmierć, Toruń-Poznań, Wydawnictwo Edytor.

Vila T. D., Darcy S., González E. A. (2015) Competing for the disability tourism market - a comparative exploration of the factors of accessible tourism competitiveness in Spain and Australia, „Tourism Management”, 47, s. 261-272. 
Zajadacz A. (2012) Turystyka osób niesłyszq̨cych - ujęcie geograficzne, Poznań, Bogucki Wydawnictwo Naukowe.

Żuraw H. (1996) Uczestnictwo kulturalne młodzieży niepełnosprawnej, Warszawa, Wydawnictwo „Żak”.

Żyta A. (2014) Niepełnosprawność intelektualna - najnowsze zmiany terminologiczne i diagnostyczne w świetle DSM-5, ICD-11 oraz AAIDD, „Niepełnosprawność i Rehabilitacja", nr 1, s. 17-26.

\section{Akty prawne}

Rozporządzenie Ministra Edukacji Narodowej z dnia 14 lutego 2017 r. w sprawie podstawy programowej wychowania przedszkolnego oraz podstawy programowej kształcenia ogólnego dla szkoły podstawowej, w tym dla uczniów z niepełnosprawnością intelektualną w stopniu umiarkowanym lub znacznym, kształcenia ogólnego dla branżowej szkoły I stopnia, kształcenia ogólnego dla szkoły specjalnej przysposabiającej do pracy oraz kształcenia ogólnego dla szkoły policealnej, Dz.U. z 2017 r., poz. 356.

\section{Źródła internetowe}

Olbrycht K., Edukacja kulturalna - potrzeby, uwarunkowania, perspektywy, 2014, https://www.scribd.com/document/339321351/Edukacja-Kulturalna-KatarzynaOlbrycht [dostęp: 5.11.2019]. 